\title{
TOWARDS REALISM IN LEGISPRUDENCE
}

\section{JULIUS COHEN $\dagger$}

ON paper, at least, the pragmatic revolt against arid conceptualism in the law is perhaps one of the most significant developments of modern jurisprudence. Pragmatists, functionalists, experimentalists-m "realists" of all shades: Holmes, Pound, Cook, Llewellyn, Radin, Arnold, and Frank, to mention but a few-though flying different banners, and employing different weapons of warfare, stormed the citadel of the formalists, united in the belief that the meaning of legal concepts is to be found in the consequences that they produce, that is, in terms of human gains and deprivations. ${ }^{1}$ Actually, the "storming" was more on paper than on the battlefield, with victory claimed only by those optimistic generals who take the long range view of the future and blithely write off the present as having passed. The foot-soldiers in the court-room and in the law schools are still engaged in heavy combat; to them, the present is still very real, and the outcome of the struggle by no means certain.

What is to be deplored, however, is less the lag between plan and execution than the fact that the attack upon the formalists of the law has been planned for only one front-the judicial. Holmes' critique of the imbalance between "logic" and "experience," 2 Pound's aspersions upon the "mechanical" in legal thinking, ${ }^{3}$ Cook's exposure of the manipulative aspects of the legal syllogism, ${ }^{4}$ Llewellyn's plea for a "look-see" on how the law actually works, ${ }^{5}$ Radin's "legal realism," Arnold's "folklore,"7 Frank's diatribes against the meaninglessness of legal "rules,"8 Morris Cohen's criticism of the "phonograph theory" of the law, ${ }^{9}$ Felix Cohen's barbs on "transcendental nonsense" ${ }^{10}$-all of

$\dagger$ Professor of Law, University of Nebraska.

1. For a general picture of American "realism" and "realists," see GArLAN, Legar REALISM AND JUSTICE (1941). The expression "gains and deprivations" as used here owes its immediate origin to Harold D. Lasswell's "indulgences and deprivations." Sce his Describing the Contents of Commmunications in SMrte, Lasswerc \& Casex, PropagnNda, Connunication and Public Opinion 74 (1946). The more remote origin for both is, presumably, Bentham's concept of "pains and pleasures."

2. Holmes, The Comaron Law 1 (1881).

3. Pound, Mechanical Jurisprudence, 8 CoL. L. REv. 605 (1908).

4. W. W. Cook, Scientific Method and the Law, 13 A.B.A.J. 303 (1927).

5. Llewellyn, Some Realism about Realism-Responding to Dean Pound, 44 Hasv. L. REv. 1222 (1931).

6. Radin, Law as Logic and Experience (1940); Radin, Legal Realism, 31 Col. L. REv. 824 (1931).

7. ARNold, The Folkrore of CAPITALISM (1937).

8. Frank, LaW aNd the Modern Mind (1930).

9. M. R. CoHEN, Law aNd the Soctal ORder 112 et seq. (1933).

10. F. Cohen, Transcendental Nonsense and the Functional Approach, 35 Cor. L. Rev. 809 (1935). 
these were, in the main, protests against the prevailing myths surrounding judicial law. They stripped judges of any pretensions of being without predilections, or of being anything other than human. More important, they gave support to the view that a great deal of judicial law was judge-made and not judge-discovered, that judges actually legislated-that their so-called judicial "logic" was nothing more than convenient trappings which concealed their real role as policymakers. Though exposés, they were not intended to put a stop to judicial policy-making. On the contrary, it was assumed that such policymaking was, in the nature of things, inevitable. It was hoped, however, that, by bringing the process to the level of consciousness, it could be made more rational. Indeed- "policy-making," being a manifestation of ethics, and the "rational" being the ideal of science, it was hoped that in judicial policy-making would come a working partnership between ethics and science, in which science would be given the opportunity to illuminate the pathways of conflicting policy considerations.

But why not legislative policy-making as well? In an area in which the scope of policy-making is considerably greater-in Congress, in the state legislatures, in municipal councils, in administrative tribunals, can it be said that the working partnership is less needed? Assuming much of judicial law to be nothing more than policy-making, is there anything inherently unique in its make-up or in its impact upon human relations to justify the realists in singling out this area of policy-making as the major target of their attacks? Is one to assume that policymaking on the legislative level is not in need of a good dose of the same kind of "realism"? How explain so bold an attack on so narrow a front?

Perhaps the basic reason is the ingrained habit of regarding law as genuine only if it is labelled "judge-made." Thus, for example, the view of Holmes that: "The prophecies of what the courls will do in fact, and nothing more pretentious, are what I mean by the law;" 11 and the position of John Chipman Gray that statutes are merely one of many "sources of law." 12 To such realists, law is simply a forecast of the manner in which the force of government will act upon an individual; and inasmuch as the impact of government is felt primarily through the courts (so they assumed), they reasoned that law and the decisions of courts are synonymous. This thought pattern is understandable when considered in the light of an ingrained tradition that considered legislation as nothing more than a meddlesome intrusion upon the mighty fortress of the common law. ${ }^{13}$ It becomes even more understandable in view of the fact that the law schools, from whence

11. Holmes, The Path of the Law, 10 HaRv. L. Rev. 457, 461 (1897).

12. J. C. Gray, The Nature and Sources of Law $\$ 191$ (1909).

13. Pound, Common Law and Legislation, 21 HARv. L. Rev. 383 (190S). 
many of the paper attacks of the realists have been launched, have for so long been geared almost exclusively to the Langdellian case system of teaching. Legislative law is dealt with not as one of the prime sources of policy-making, but merely as a factor which a court must consider in reaching a decision in a litigated issue.

But the fiction that courts are the only conduits through which the force of government is carried to the individual ignores what should now be obvious to any realist-that, in human experience, obedience to legislative policy does not necessarily await the judicial green light. Legislation calling for a "blackout" during an air-raid does not have to be litigated before it is obeyed. And, needless to say, where there is obedience there is impact. With Legislation fast becoming one of the major courses in the curricula of our law schools, ${ }^{14}$ with significant departures being made from the traditional method of "case" instruction, with growing recognition of the fact that lawyers need to be trained to deal with policy-making on all levels, whether judicial or legislative ${ }^{15}$ - there is reason to hope that the fiction will not, like Banquo's ghost, remain long to haunt us. At least, there are signs that one of its major props-the schools-will no longer give continued support to the "monopoly of the judicial point of view." 16

For the realist, then, policy-making is the common denominator of both the judicial and legislative processes. But the similarity does not stop here. If arid conceptualism is descriptive of policy-making on the judicial level, the conceptualism is no less arid on the legislative; and, if there is a crying need for "realism" in the one area, there is more than sufficient evidence of such need in the other.

As early as 1921, Cardozo publicly voiced concern over the fact that "courts are not helped as they could and ought to be in the adaptation of law to justice." 17 "The duty must," he said, "be cast on some man or group of men to watch the law in action, observe the manner of its functioning, and report the changes needed when function is deranged." ${ }^{18}$ His plea for the creation of a Ministry of Justice was prompted by the belief that, unless the effects of judge-made law are constantly measured and evaluated, that is, in terms of its impact upon those who are affected, it becomes sterile and defeats the ends of

14. In the 1949-50 Teachers' Directory of the Association of AMerican Law ScHools, sixty-eight teachers are listed as handling or participating in courses in Legis. lation. Just a few years ago teachers of Legislation in law schools were virtually unheard of.

15. See, for example, Lasswell \& McDougal, Legal Education and Public Policy, 52 Yale L.J. 203 (1943); J. Cohen, Crisis in Legal Education, 15 U. of Cur. L. TEv. 588 (1948).

16. This expression was, Ernst Freund's in his $A$ Course in Statutes, 4 Ax. L. Schoor Rev. 273, 275 (1917).

17. Cardozo, A Ministry of Jihstice, 35 HARv. L. REv, 113 (1921).

18. Id. at 114 . 
justice. The need is for the facts-the most accurately ascertainable facts available-concerning the effects of such law in operation. Without such facts constantly available to the judges, there is danger that socially undesirable policies will be perpetuated by the application of a relentless logic, which places consistency above the demands of justice. That other distinguished members of the profession have continued to urge the establishment of a Ministry of Justice ${ }^{19}$ is evidence that the plea has gone unheeded. At best, however, it has been taken as one of confession and avoidance confession of the need, but avoidance of a whole-hearted effort to cope with it.

On the judicial level, the need, then, is still with us; and the efforts to cope with it recognize that judicial policy-making is blind unless it is bottomed on reliable information concerning what the policy has done, and reliable estimates of what it will do-in terms of human gains and deprivations. It impliedly admits that this information cannot with complete reliance be obtained from the briefs or arguments of counsel representing the adversary interests involved; that this body of knowledge must come from some reliable independent source. It recognizes the need for accurate measuring rods of human behaviormeasuring rods the creation and application of which would tax the ingenuity and skills of our best social scientists.

The blindness of policy-making and the need for scientific measuring rods are no less evident on the legislative level. ${ }^{\mathrm{N}}$ On this level, the chief instrument for ascertaining the facts concerning the effects of past social policy and the estimates of what a future policy will probably do is the "hearing" before a legislative committee. It is before the committees - standing and special - that the "facts" concerning a pending policy issue before Congress are paraded. Presumably, it is from a careful weighing of these "facts" that a policy is born-at least so the fiction goes. But what facts? Facts so reliable as to foreclose disputation? And who presents the facts? Impartial, independent students, who are not only competent to gather them but also not afraid of letting the "chips fall where they may"? Or is it by representatives of adversary interests who slant the facts to support the policy sought to be enacted? In brief, what is the nature of the fact-finding process which supposedly underlies legislative policy-making? Perhaps a clue to the

19. See Frank, Courts on TrIaL 291 (1949); S. Glueck, The Mfirisiry of Justice and the Problenn of Crime, 4 ANerican Review 139 (1926); Lobinger, Precedent in Legal Systems, 44 Mircr. L. REv. 955 (1946); Yntema, Legal Scienec and Reform, 34 CoL. I. REV. 207, 215-29 (1934).

20. This was recognized as early as 1823 by Bentham, who urged the creation of a Ministry of Justice as a method for better preparing legislators for their tasks as policymakers. On this, see Pound, $A$ Mintistry of Justice as a Mlcans of Mfoling Progress in Medicine Available to Courts and Legislatures, $10 \mathrm{U}$. of Crr. L. Rev. 323, 331 et seq. (1943). 
workings of this process-at least on the federal level-can be found by examining its operation in connection with three of the most controversial policy issues which faced the first session of the 81st Congress -(1) the Taft-Hartley Act, (2) basing points, and (3) displaced persons.

The Taft-Hartley issue involved, among other things, heated controversies over what the Taft-Hartley Act actually accomplished in practice. The proponents of repeal claimed that the Act produced certain results; those who advocated the retention of the Act denied that it produced these results. There were large areas of agreement as to the ultimate ends an appropriate Labor-Management Relations Act should achieve; but much of the controversy was concerned with whether the Taft-Hartley Act, as a means to these ends, did accomplish them during its period of operation. For example, both sides publicly avowed that legislation regulating labor-management relations should (1) not discourage membership in labor unions; (2) improve the processes of collective bargaining; (3) insure the greatest effectiveness of the conciliation service; (4) lessen the amount of labor-management strife; (5) eliminate Communists from positions of control in labor unions; (6) increase the efficiency of the National Labor Relations Board; (7) be impartially administered; and (8) provide an effective method for settling national emergency disputes. But both sides were in heated disagreement over whether the machinery of the Taft-Hartley Act advanced or retarded these ends. The facts with respect to the accomplishments of the Act were in dispute.

How were these facts resolved-if at all? The chief forums made available for this purpose were the Committees of the House and Senate, to which bills calling for repeal of the Taft-Hartley Act were referred for a "hearing"-a normal procedure for airing considerations which underlie legislative policy decisions. Those familiar generally with the workings of the hearing process agree that the hearings on these bills followed rather conventional lines. Spokesmen for the pros and cons-carefully screened and selected by the majority and minority leadership on the Committee-were permitted to appear as "witnesses" to "testify." In the main, these consisted of key governmental officials charged with administering the Act, representatives of powerful management and labor groups, and independent "experts" in labor-management relations. Though considerably more informal than a judicial proceeding involving the trial of an issue of fact, it is evident that a certain flavor of the judicial prevailed at the hearings. The "witnesses" were adversaries-parties in interest. Even the "experts" appear to have been chosen for their particular slant on the issues at hand. The chief method of "proof" was by testimonial - testimonials not only as to what the law ought to be, but what the Taft-Hartley Act actually did. 
Additional major types of evidence included sporadic "case studies" of experiences under the Act, opinions from newspaper editorials and magazine articles, assumed facts, a few scattered statistics from which conflicting inferences could be drawn, letters and telegrams from constituents, the results of questionable questionnaires aimed at recording group attitudes on labor policy, etc. But throughout the 1700 printed pages upon which the House hearings were recorded, and throughout the 3500-odd pages which were consumed on the Senate side, one looks in vain for a reliable resolution of the conflicting versions of many of the major "facts" upon which a great number of the conflicting policies presumably were bottomed. Facts which should and could have been resolved remained in the realm of disputation-each side presenting competing hypotheses as to what they were, and then drawing logical, but competing, policy conclusions with respect to them. ${ }^{21}$ There was very little evidence which was aimed at reducing these hypothetical fact constructs to relative certainty.

The use of testimonials is understandable, of course, in instances in which opinion is sought on the probable course of fuiture conduct. But what of the above-mentioned facts in dispute that related to the past? Many of them were, admittedly, difficult to establish. But this does not mean that better methods than those used at the hearings were not available for tracking many of them down-for reducing the area of

21. Note the conflicting views concerning the effects of the Taft-Hartley Act during its period of operation:

(a) on whether it hampered union organizing-contrast the statement of Ira MLosher of the NAM with that of Arthur J. Goldberg, General Counsel, CIO. Hcarings bcfore Committee on Labor and Public Welfare on S. 249, 81st Cong., 1st Sess. 2336 and 439 (1949) (Hereafter Hearings).

(b) on whether it improved the processes of collective bargaining-contrast the statement of Ira Mosher of the NAMI with that of Professor Nathan P. Feinsinger. Hearings 2389 and 2571.

(c) on whether it increased the effectiveness of the government conciliation servicecontrast the statement of Almon Roth, President of the San Francisco Employers Council, with that of Walter Mfunro. Hearings 537 and 2072 et seq.

(d) on whether it lessened the amount of labor-management strife-contrast the statement of Almon Roth with that of A. F. Whitney of the Brotherhood of Railway Trainmen. Hearings 592 and 2748-9.

(e) on whether it eliminated Communists from positions of control in labor unions -contrast the statement of Robert N. Denham with that of Secretary of Labor Tobin and Senator Humphrey. Hearings 1076 and 342.

(f) on whether the separation of functions of the Board and the General Counsel increased the efficiency of the NLRB-contrast the statement of George B. Christensen, Attorney, with that of Arthur J. Goldberg. Hearings 2651 and 481.

(g) on whether it assured the impartial administration of the Act-contrast the statement of Ira Mosher with that of Arthur J. Goldberg. Hearings 2396 and 482.

(h) on whether it provided an effective method for settling national emergency disputes-contrast the statement of Senator Forrest Donnell with that of William H. Davis. Hearings 924 and 893. 
disputation to the barest minimum. As clumsy and as crude as many of the present tools of the social sciences are, no one can seriously doubt that they could have yielded findings considerably more reliable than those obtained at the hearings. Given the opportunity, experiments for obtaining the answers to such fact controversies could have been designed by competent social scientists. The methods used and the findings that resulted could have been subjected to as rigorous a critical scrutiny as one can apply to experiments in the physical sciences.

This assumes that the basic purpose of a legislative hearing is to get at the facts, to make the policy decisions as rational as possible. It is doubtful, however, whether such an assumption is justified. Not infrequently, the hearing is used merely as a political sounding board for legislative policy-makers. It provides them with an opportunity to ascertain what power groups support or oppose a certain legislative proposal; it gives them an opportunity to assess not only their strength of conviction, but their relative power; it serves as an instrument for calculating the political advantages and disadvantages of casting a "yea" or "nay" vote if and when the measure reaches the floor. Not infrequently, too, one finds the hearing used as a device to be manipulated by those who, through party government and a system of seniority, control the machinery and the personnel of the committee. The manipulation may take many forms. The hearing might, for example, be used as a method by which those already committed to a legislative policy give that policy an aura of well-reasoned respectability by making it appear that the decision was arrived at on rational grounds. This method is familiar to policy-makers on the judicial level who often endeavor to buttress a decision with judicial logic long after that decision was reached on other than logical grounds. One will find all of these purposes-and more-operative in the hearings on the TaftHartley issue.

Those who control the committee machinery may also use the hearings as a device to suppress facts salient to a policy issue because of the fear that an exposure of the facts might lend support to a policy which they do not wish to be enacted into law. There were at least two examples of this in the 81st Congress. The first involved the controversy over displaced persons legislation. The proponents of a liberalized Displaced Persons Act found that it was extremely difficult, if not impossible, to get before the Senate Judiciary Committee (and, therefore, the public) data to show the inadequacies of existing laws, particularly as they affected the European Catholic, Protestant and Jewish victims of the last war. Sixteen Senate bills concerning this subject were introduced during the first session-eight in January, two in February, four in March, one in April and one in May. No public hearings on any 
of these bills were held until the 26th of July. On that date, it was made clear by the Chairman of the Judiciary Committee, Senator McCarran, that the hearings would not be concerned with the immediate problem of the European displaced persons, but with displaced and helpless persons all over the world-the Pakistanis, the Arabs, the Greeks, the Chinese, etc. As a result, those who had data to present concerning the European displaced persons situation, even the members of the Displaced Persons Commission who were administering the Act, were for a long time denied the opportunity to appear before the Committee. ${ }^{22}$

The second example related to the much fought-over "basing points" issue, a controversy brought to a head by the introduction of several bills purporting to allow the continuation of certain restrictive trade practices which had been outlawed by the Supreme Court. The manipulatory aspects of the hearing process were dramatized in a speech on the House floor by Representative Patman of Texas, an outspoken opponent of the moratorium measure. In complaining that no opportunity was had for adequate hearings on the proposed measure, he stated:

"I grant that this might happen in Russia where they have a dictatorship, or it could have happened under Hitler or under Mussolini, but I am surprised that here in the U.S.A., the United States of America, that the gentleman would try to force a bill of this magnitude through the House of Representatives and through Congress without any public and printed hearings. Then, when we come to discussing it, the committee that is in favor of the bill has 3 hours, and $I$ am given but 20 minutes in which to oppose it. . . . [T] committee owes us the duty of holding hearings and bringing those hearings back in here so that we will know what every word, and every phrase, and every sentence of every paragraph means. They have not done that. That is not the American way of enacting laws." 23

One should add that when those who by control of the hearing process not only suppress the facts, but by doing so draw from it and propagate the false inference that "silence means acquiescence," then the manipulation yields double dividends. ${ }^{24}$

22. Despite the absence of witnesses prepared to demonstrate the urgency of liberalized displaced persons legisiation, it was noted in the Washington Post, July 28, 1949, p. 4, that: "McCarran said at a hearing of his Immigration Subcommittee that he saw 'no reason' for rushing changes in the present D.P. law, labeled discriminatory by President Truman, nor for taking any action to increase the D.P. quotas until next May."

23. 95 Cong. Rec., Part 7, 9040, 9041 (1949).

24. An example of the drawing of such an inference of acquiescence may be found in the minority report on the Hearings on S. 249, the bill to repeal the Taft-Hartley Act. In commenting on the desirability of continuing the provision which outlawed mass picketing, the report states: "There was very little testimony against this Tait-Hartley provision at the 1949 hearings and no specific instances alleging it had worled an injustice 
If these examples of the legislative hearing process were the exception rather than the rule, there would not be too great a cause for concern, even though the three legislative policy issues were of widespread importance. One suspects, however, that accurate, objective factfinding to illuminate the pathways of proposed policy decisions is, by and large, not the chief function of the hearing process as it is used today. Exceptions there are, of course, but their existence as exceptions would seem merely to strengthen the suspicion of the general rule.

If this is true, what other reliable instruments of fact-finding are available to the legislative policy-makers? The Legislative Reference Services on the House and Senate side are not geared to undertake such research, their main function being to gather secondary reference materials and to assist in the technical job of bill drafting. ${ }^{25}$ Occasionally Congress authorizes committees to undertake specialized studies of problems which are ripe for legislation. Often this is taken as an invitation for junkets by legislators to obtain information "first hand." If the problem is in any way complicated, this information can at best: be little more than quick impressionistic reactions. Sometimes committee staff "experts" are sent out into the field to gather pertinent in. formation. Many of these so-called "experts" are incompetent to perform a first rate job of research, especially if it involves the study of complex social, economic and psychological phenomena. Among them it is common to find lawyers, self-styled economists, journalists, public relations men, and political "hangers-on," who have had no specialized training in the complicated fields of the social sciences. But even with these defects, the number of authorized field studies is exceedingly small; and upon examination one will find many of them nothing more than decentralized hearings with the same weaknesses that one observes in the hearing process generally. Very rarely one finds a study to match the quality of the TNEC reports, or the quality of the personnel that was engaged to prepare them. Even rarer are legislative studies designed to examine the "before and after" of laws in operation.

It is interesting to recall, for example, the intensity of the arguments concerning the efficacy of the Administrative Procedure Bill. The predictions of what the proposal, if enacted, would do, were countless. The bill was finally passed and has been on the books for approximately four years. Despite the tremendous importance of this measure, one has yet to find evidence of any serious attempt by Congress to ascertain whether any of these predictions came true, or whether the Act achieved the purposes for which it was were presented to the committee." SEN. REP. No. 99, PART 2, 81st Cong., 1st Sess. 24 (1949).

25. For a discussion of the work of the Legislative Reference Services, see Hcarings before the Joint Committee on the Organization of Congress on H. Con. Res. 18, 79th Cong., 1st Sess. 413-30, 455-66 (1945). 
passed. ${ }^{25}$ What seems to give impetus to an investigation of law in action is some dramatic dislocation or disaster which arouses widespread public indignation. Thus it took nearly one hundred deaths resulting from the use of "Elixir Sulfanilimide" in 1938 to convince Congress that the 1906 Federal Food and Drug Act did not offer the consuming public sufficient protection. ${ }^{27}$

There are, of course, notable instances of significant studies undertaken by the Executive arm of the Government-for example, the work of the Division of Planning and Surveys in the Department of Agriculture, the National Resources Planning Board, the Bureau of Labor Statistics, the Federal Reserve Board; and by such private agencies as the Brookings Foundation and the National Bureau of Economic Research. These can and have been utilized by Congress in its policymaking deliberations. But one would surmise that the total of such studies would constitute only an infinitesimal part of the almost countless policy issues that are considered and acted upon during each session of Congress. It seems fairly safe to assume that, by and large, the "noise principle" as suggested by William James is still the dominant operative force in legislative policy-making. As paraphrased by T. V. Smith, the principle is to "wait to see who hollers, and then relieve the hollering as best you can to see who else hollers." 23

It should be evident from all of this that, not only on the judicial level, but on the legislative level as well, there is great need for better fact-finding methods if policy-making is to become more rational. If something akin to a Ministry of Justice is needed to assist the courts in gaging the efficacy of past and proposed judicial policy-making, something similar but of considerably greater scope is needed for legislative policy-making. In its ideal form, it would require a vast army of our very best scientists-social and physical-who would be authorized to undertake an untold number of studies: diagnostic, to determine whether action is required; prognostic, to forecast trends and plan future needs; evaluative, to assess the efficacy of existing programs;

26. It is still true that "the need for a continuous testing apparatus is apparent. The recommendation of the Attorney General's Committee that an Office of Federal Administrative Procedure be established to launch continuous scientific studies of the efficacy of established administrative procedures is as salutary now as it was when originally made. The creation of such machinery would do much to dissipate the apprehensions of those who doubt the purpose of the Act to be the improvement of the administrative process. Even more, it would provide the means to dispel, once and for all, whatever errors the critics of the Act may have made in predicting that its provisions will not prove worlable" See J. Cohen, Legislative Injustice and Supremacy "of Law," 26 NED. L. REv. 323, 345 (1947).

27. See Cavers, The Food, Drig and Cosmetic Act of 1935; Its Legislatize Hisfory and Its Substantive Provisions, 6 LAW \& Contearp. Pron. 2, 20 (1939).

28. Smith, Castom, Gossip, Legislation, 16 Soctal Fosces 24, 34 (1937). 
fact studies, to illuminate the pathways of alternative policy choices. ${ }^{20}$ In brief we must use all phases of applied research which would permit a transplantation of our best scientific knowledge to the field of policymaking.

Of course this is asking for the moon, but it is a target towards which to shoot. Its realization in its ideal form would obviously be hampered by many conditions, the most serious of them being: (1) the unwillingness of some policy-makers to assume the "rational" as an ethical postulate; (2) the undeveloped state of the social sciences; and (3) the fear that science will dictate what people should want. But the first should not deter one from the pursuit of the "rational" as a basic value in a democratic society. Nor need the second factor cause one to shy away from whatever contributions, however few, the social sciences have to make. And there have been a few, despite the attacks of those who refuse to recognize the worth of any advance that does not measure up in magnitude to the accomplishments of the physical sciences. Even in its primitive state, social science today can go far beyond the capacity of our average legislative policy-makers and their coteries of advisers in presenting a fairly accurate picture of the salient factors, e.g., conditions, resources and possible alternatives, which are germane to the making of rational policy judgments. ${ }^{30}$ Finally, as to the fear that science will become the dictator and not the adviser, the following observation should provide a modicum of assurance:

"no science tells us what to do with the knowledge that constitutes the science. Science only provides a car and a chauffeur for us. It does not directly, as science, tell us where to drive. The car and the chauffeur will take us into the ditch, over the precipice, against a stone wall, or into the highlands of age-long human aspirations with equal efficiency. If we agree as to where we want to go and tell the driver our goal, he should be able to take us there by any one of a number of possible routes, the costs and conditions of each of which the scientist should be able to explain to us. When these alternatives have been made clear, it is also a proper function of the scientist to devise the quickest and most reliable instrument for detecting the wishes of his passengers. But, except in his capacity as one of the passengers, the scientist who serves as navigator and chauffeur has no scientific privilege or duty to tell the rest of the passengers what they should want." 31

29. This follows, somewhat, the classificatory scheme developed by the Columbia University Bureau of Applied Research. See Merton, The Role of Applicd Social Sciculce in the Formation of Policy: A Research Memorandum, 16 Pmilosopny of Scrence: 161, 174 (1949).

30. On this point, see Shils, Social Science and Social Policy, 16 Punlosoprux of SCIENCE 219, 236-7 (1949).

31. Lundberg, Can Scrence Save Us 31 (1947). See also Benoit-Smullyan, Valile Judgments and the Social Sciences, 42 Jounal of Philosophy 197, 209 (1945). 
Realism in jurisprudence calls for a working arrangement between science and judicial law. Realism in legisprudence calls for a similar arrangement with legislative law. Both are but facets of a single purpose-the illumination of the pathways of policy-making with the best light that human knowledge and experience can possibly provide. Both assume that "law" can properly be understood only by a constant examination of the nature of its impact upon those whom it affects. But neither necessarily minimizes the tremendous difficulties in the way of arranging a rendezvous between science and policymaking. Some policy-makers may resent the intrusion of science out of fear that it will expose their hand, or invade an area which they regard as their exclusive domain; ${ }^{32}$ others may try to exploit it only when it will bolster or adorn a decision reached on other grounds; ${ }^{33}$ still others, impressed only with the immaturity of the social sciences, are frightened at the risk of having a rendezvous with a minor. Difficulties there are, to be sure, but the approach seems to hold the only hope for those who still cling to the pursuit of reason as the sine qua non of the democratic way of life.

32. On this latter point, see Shils, supra note 30 , at 234-5.

33. This is the view of Hans J. Mrosgentenau in his Scientific Alan vs. Power Polmmes 219 (1946). Unfortunately, Professor Morgenthau holds out no more hope than this for science in relation to policy-making. 


\section{THE YALE LAW JOURNAL}

\begin{tabular}{lll}
\hline VolUME 59 & APRIL, 1950 & NUMMer 5 \\
\hline
\end{tabular}

\section{EDITORIAL BOARD \\ Donald F. TURner \\ Editor-in-Chief \\ Norman Redich \\ Executive Editor}

Arnold Hoffman
Llewellyn P. Young
Comment Editors

GERALD D. KatCHER

Case Editor

Leo P. Arnaboldi, Jr.

CURTIS J. Berger

HETNZ F. BRAUER

JOHN G. BURNETT

James C. Cochrane

Harold D. FIEID, JR.

RICHARD M. FITZSIMMONS

DANIEZ J. FreED

BERNARD $\mathrm{H}$. GREENBERG
EDWard N. BenjaMin
Article and
Book Review Editor
WirunM D. GinN

RJGISARD F. IaL

Note Editors
Artaur M. Michaelson

Managing Editor

Williams E. Hegarty

JAMES D. HIIBORN

ROBERT K. LIFTON

ROBERT P. LYONS, III

Burke Marshall

Patricta A. McGowan

Donald L. MEDLOCK

WIILIAMK R. PERLIK

JEROME PRESTON, JR.

\author{
WILLIANS DILL ROGERS \\ WhitNey N. Seymoun, JR. \\ Metuin G. Sunsiss \\ Monroe S. Singer \\ Stuart W. Tuayer \\ Enjuote E. Vose \\ ANDREW M. WOOD \\ RAYHOND H. YoUne \\ Edgar A. Zingman
}

\section{Marie McManon Business Secretary}

ROBERT M. CABOT

Student Business Manager

Subscription price $\$ 5.50$ per year

This number, $\$ 1.00$

Canadian subscription price $\$ 6.00$ per year; Foreign, $\$ 6.25$ per year; for prices on other issues inquire

The Yale Law Journal Company, Box $401 A$ Yale Station, New Haven, Connecticut

\section{CONTRIBUTORS TO THIS ISSUE}

Arthur Linton Corain. B.A. 1894, University of Kansas; LL.B. 1899, M.A. (hon.) 1909, Yale University. Author Cases on Contracts ; editor ANson on ContrActs. Coreporter, American Law Institute Restatement of Contracts. Advisor, Sales Section, American Law Institute Uniform Commercial Code. William K. Townsend Professor of Law, Emeritus, Yale University.

Peter Mrcler. B.A. 1945, Columbia University ; LL.B. 1948, Yale University. Member of the New York Bar.

Jurrus Cones. B.A. 1931, M.A. 1932, LL.B. 1937, West Virginia University ; LL.M. 1938, Harvard University. Author Materials aNd Problems oN Legrslation (1949). Professor of Law, University of Nebraska College of Law. 